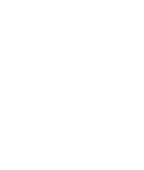
ANNUAL Further
REVIEWS

Click here for quick links to Annual Reviews content online, including:

- Other articles in this volume

- Top cited articles

- Top downloaded articles

- Our comprehensive search

Annu. Rev. Sociol. 2013. 39:359-78

First published online as a Review in Advance on May 22, 2013

The Annual Review of Sociology is online at http://soc.annualreviews.org

This article's doi:

10.1146/annurev-soc-071312-145639

Copyright (c) 2013 by Annual Reviews. All rights reserved

\section{Racial Formation in}

\section{Perspective: Connecting} Individuals, Institutions, and Power Relations

\section{Aliya Saperstein, ${ }^{1}$ Andrew M. Penner, ${ }^{2}$ and Ryan Light ${ }^{3}$}

\footnotetext{
${ }^{1}$ Department of Sociology, Stanford University, Stanford, California 94305; email: asaper@stanford.edu

${ }^{2}$ Department of Sociology, University of California, Irvine, California 92697; email: penner@uci.edu

${ }^{3}$ Department of Sociology, University of Oregon, Eugene, Oregon 97403; email: light@uoregon.edu
}

\section{Keywords}

racialization, ethnic boundaries, identification, classification, inequality

\begin{abstract}
Over the past 25 years, since the publication of Omi \& Winant's Racial Formation in the United States, the statement that race is socially constructed has become a truism in sociological circles. Yet many struggle to describe exactly what the claim means. This review brings together empirical literature on the social construction of race from different levels of analysis to highlight the variety of approaches to studying racial formation processes. For example, macro-level scholarship often focuses on the creation of racial categories, micro-level studies examine who comes to occupy these categories, and meso-level research captures the effects of institutional and social context. Each of these levels of analysis has yielded important contributions to our understanding of the social construction of race, yet there is little conversation across boundaries. Scholarship that bridges methodological and disciplinary divides is needed to continue to advance the racial formation perspective and demonstrate its broader relevance.
\end{abstract}




\section{INTRODUCTION}

Race: "a concept which signifies and symbolizes social conflicts and interests by referring to different types of human bodies" (Omi \& Winant 1994, p. 55)

Racial formation: "the sociohistorical process by which racial categories are created, inhabited, transformed, and destroyed" (Omi \& Winant 1994, p. 55)

Racial project: the "building block" of racial formation; "an interpretation, representation, or explanation of racial dynamics, and [a simultaneous] effort to reorganize and redistribute resources along particular racial lines" (Omi \& Winant 1994, p. 56; see also Carbado \& Harris 2012)
The social constructivist turn has been a fruitful one for sociology. Despite its critics (e.g., Hacking 1999), the recognition that everything from social norms to categories of analysis are historically situated, context specific, and subject to processes of both resistance and reproduction (Berger \& Luckman 1966) has invigorated numerous subfields, including the sociology of race and ethnicity. At the same time, the proliferation of "scare quotes" around key axes of social inequality that were long seen as objective measures of difference seems to have frightened some scholars away from fully exploring the implications of constructivist claims for the broader body of sociological research: Constructivism, although readily acknowledged, has been unevenly engaged across sociological subfields.

Thus, in the spirit of bridging academic boundaries, our review of recent research on the social construction of race aims to provide an overview of the field for the nonspecialist. Although a nodding consensus exists in sociology that race is a social construction, we argue that the discipline as a whole has a narrow understanding of this widely accepted claim, in part because its implications for the conduct of research beyond the field of race and ethnicity remain underappreciated (see, e.g., Morris 2007, Saperstein 2013). To address this gap and to underscore the wide-ranging empirical support for the larger theoretical paradigm, we synthesize the evidence that has accumulated over the past several decades on processes of "racial formation" (Omi \& Winant 1986, 1994). In doing so, we also highlight some of the internal divisions in the field-in particular, differences in scope conditions or levels of analysis—offering specialists and nonspecialists a unique perspective on the literature. We conclude by noting the need for more research that explicitly crosses macro-micro-meso divides to reveal whether and how racialization processes work in concert across different domains of social life to shape ideas of racial difference and reproduce the larger system of social inequality.
Multilevel studies that make these connections among individuals, institutions, and the broader terrain of power relations will not only advance scholarship on race and ethnicity but also help further demonstrate the utility of incorporating a constructivist approach to these slippery concepts in social science research.

\section{CORRALLING THE CONCEPT OF RACE: HISTORY, TERMINOLOGY, AND METHODOLOGY}

The position that race is socially constructed developed, in part, as a response to claims that social inequalities, for example in educational achievement between blacks and whites in the United States, were rooted in biological or genetic differences. The argument that such disparities are shaped more by politics and environment than by biology dates at least to the debunking of racial craniometry by Franz Boas in the early twentieth century (see Gravlee et al. 2003), and arguably to W.E.B. Du Bois (1899) and beyond. Other influential figures contributing to the social constructivist perspective on race and ethnicity over the past century include Max Weber (1978), Ashley Montagu (1942), and Fredrik Barth (1969).

More recently, the literature has been shaped by the seminal work of sociologists Michael Omi and Howard Winant $(1986,1994)$ in Racial Formation in the United States. Indeed, the exponential growth of sociological work on race that employs the language of social construction began around 1990 (see Figure 1 $a$ ) - the midpoint between the publication of the first and second editions of Racial Formation. Dissatisfied with scholarship that often "reduced" race to a product of other social processes and dimensions of power relations (namely assimilation/ethnicity, class, and nation), Omi \& Winant argued that social scientists needed to make race, "racial projects," and the process of "racial formation" the conceptual focus of research. 
a

Total number of articles by year

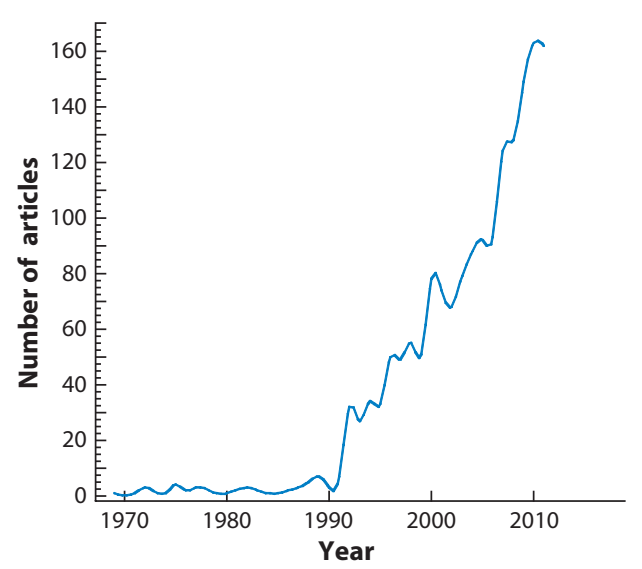

b Top citations by window

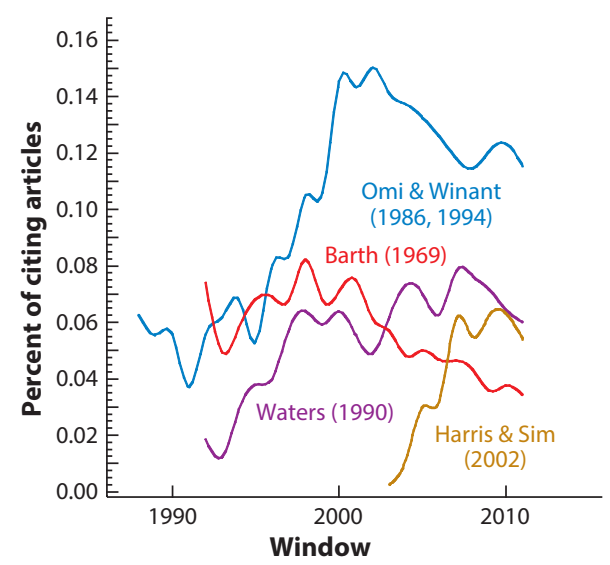

Figure 1

Trends in sociological research on the social construction of race. Note: Windows consist of articles from the labeled year to the labeled year minus a weighted lag to capture a citation "environment." For more Supplemental Material details, see the Supplemental Material online.

Racial Formation has been cited in about $6 \%$ of all articles about race in sociology since its publication, making it one of the five most cited publications in this core sociological subfield (for more details of our citation analysis, see the online supplemental material by following the Supplemental Material link from the Annual Reviews home page at http://www.annualreviews.org). ${ }^{1}$ However, the influence of Omi \& Winant's work drew initially from other disciplines, including scholars in history, education, and law, with sociology relatively late to recognize the paradigm shift (HoSang et al. 2012). Even now, citations of Racial Formation are more likely to appear in sociological articles about racism and whiteness or identification and assimilation than in articles about prejudice and segregation or work and inequality (see Figure 2).

We argue that these cleavages in the field of race and ethnicity have hampered progress on the topic and limited application of the

${ }^{1}$ The top five also include Wilson's Truly Disadvantaged, Massey \& Denton's American Apartheid, Blalock's Toward a Theory of Minority Group Relations, and Allport's The Nature of Prejudice. racial formation perspective to other areas of sociological research. Part of the challenge of generating a clear synthesis on how the social construction of race unfolds, particularly one that is accessible to nonspecialists, is precisely that the literature is not only topically diffuse, as can be seen in the citation pattern of Racial Formation (Figure 2), but also split by differences in terminology and methodology. The perennial debate over whether or not to distinguish between race and ethnicity-that is, between purportedly physical, immutable, ascribed, or externally imposed divisions and those claimed to be cultural, malleable, achieved, or self-designated-has generated one type of divide in the field (see Jenkins 1997, Patterson 1997 for discussions). Other internal divisions can be attributed to differences in theoretical commitments, methodological starting points, and social justice orientations (Bobo \& Fox 2003, Bonilla-Silva 1997, Loveman 1999, Wacquant 1997).

There is even some disagreement about when to date the emergence of race and racism. In sociology, racial ideology is often described as evolving out of the imperial encounters that marked the Age of Exploration and the 


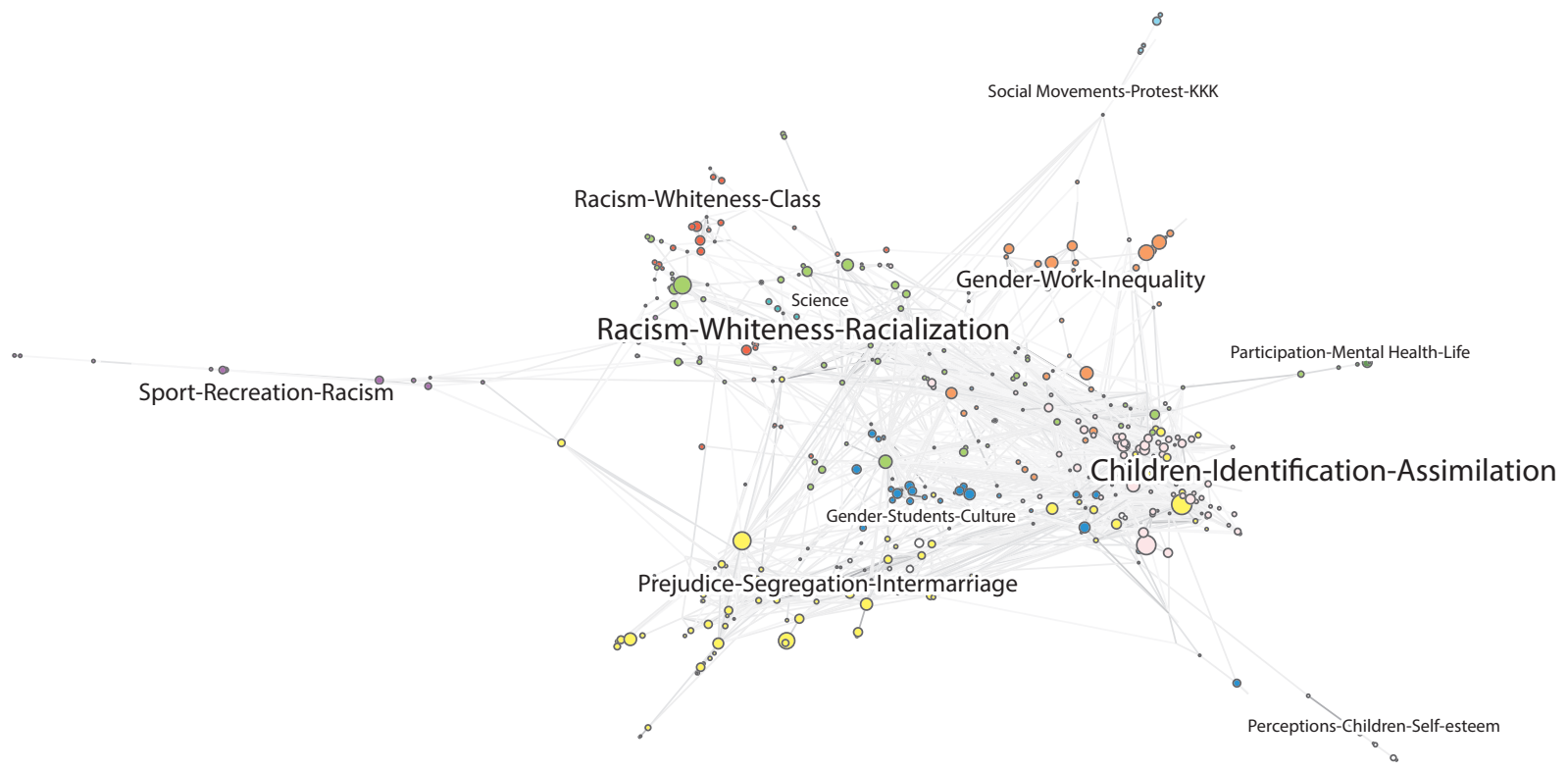

Figure 2

Social construction of race citation network for 2011 window. Note: Node sizes correspond with times cited; node colors represent communities based on Girvan \& Newman (2002); edges correspond with the cosine score based on citation overlap; labels consist of the top-three keywords; label sizes represent the percent of articles in the clusters that cite Omi \& Winant $(1986,1994)$; graph layout is VOS Mapping rendered in Pajek (see Batagelj \& Mrvar 1998). For more details, see the Supplemental Material.

Supplemental Material

beginning of the modern era (Winant 2000). From this perspective, the advent of permanent slavery and the colonization of indigenous land necessitated a new concept of inherent and inferior distinction to justify the oppression of non-European, nonwhite bodies (Smedley 2007; see also Snowden 1983). The initial focus on race as a black-white or white-nonwhite binary, at least in the United States, follows from this starting point as well. However, the utility of setting such a firm demarcation between race and not race-e.g., circa 1570 when the word entered the English language with something akin to its current meaning (Sollors 2005)—is being questioned. Historical research suggests that hierarchies of religion and class position, the major axes of premodern, internal differentiation, were also imbued with corporeal significance, as when Jews were thought to have hidden horns and tails (Thomas 2010) or Russian serfs were believed to have black bones (Kolchin 1987). Similarly, what we would now describe as European nationalities were once thought to exhibit immutable characters, predispositions, and moral failings (e.g., Douglas 2002).

Such scholarship raises questions about how to bound the concept of race. Should it be limited to distinctions based solely on readily observable, physical characteristics, such as skin tone (see Banton 2012), hair texture, and facial features? Or is it the belief in inherited difference and an ideology of permanent inequality applied to an entire population of people that delineates race (see Frederickson 2002)? Should sociologists focus on the similarities between race and other categorical distinctions (e.g., Tilly 1999, West \& Fenstermaker 1995) or the differences? The push to examine processes of racialization more broadly-highlighting the circumstances under which any category of human difference becomes associated, implicitly or explicitly, with a corporeal or inherent permanence-drew impetus from the initial formulation of Racial Formation (Omi \& Winant 1986, p. 64). Instead 
of highlighting how racial antagonisms are at their roots, for example, class antagonisms, this work shows how other nonphysical characteristics and axes of social difference get cloaked in racial language and symbolism as they come to be seen as heritable and immutable (see also Barot \& Bird 2001). However, these efforts to expand the field have also been met with criticism, as disingenuous attempts to piggyback on previously successful social movements or minimize the experience and continued reality of black-white inequality (see Thomas 2010).

A deep engagement with the sociology of race and ethnicity requires scholars to grapple with these differing perspectives and take a stance or generate a new synthesis, which will motivate their work. To assist in that effort, recent reviews provide crucial background on related issues, including conceptualizing ethnicity, race, and nationalism (Brubaker 2009) and examining processes of social and racial boundary making (Lamont \& Molnár 2002, Wimmer 2008), shifting US color lines (Lee \& Bean 2004), and comparative ideologies of racial "mixing" (Telles \& Sue 2009). Our aim is to take a wide view of the field, and thus the conceptual distinctions we have chosen to address are somewhat different. We add to these conversations by reviewing sociological research that provides evidence on the central tenets of a racial formation perspective, with a particular focus on empirical studies in the United States. Within that frame, we err on the side of inclusion, encompassing work that explicitly cites Omi \& Winant $(1986,1994)$, as well as work that simply employs the language of social construction in the study of racial and ethnic identities, categories, and boundaries. (For more details, see the Supplemental Material.)

Over the past several decades, as this field of inquiry has progressed, research has moved beyond general demonstrations of social construction to detailed investigations of racial formation processes as they unfold at the macro, micro, and meso levels of analysis. Sociologists have documented the changing racial order and which categories are most salient in particular places or times; explored how people get arrayed - or array themselves-into those categories; and examined the consequences of consciously and unconsciously organizing our schools, workplaces, families, neighborhoods, and governments around such categorical distinctions. However, most studies provide a single snapshot of a given process focused on a particular level of analysis-i.e., either macro, micro, or meso. These differences in analytic scope cut across both the topical distinctions visible in our citation analysis and the terminological debates noted above, with consequences for defining key findings in the field. Thus, the bulk of our review is organized into separate discussions at each level of analysis, in part to showcase their unique contributions to the literature on racial formation. However, we distinguish these approaches with the goal of encouraging more dialogue between scholars, not less. By juxtaposing macro-, micro-, and meso-level research on the social construction of race, we also seek to highlight the remaining gaps in our knowledge and reveal opportunities for future research that links these processes and advances our understanding of both racial formation and the causes and consequences of social inequality more broadly.

\section{THE MACRO CONTEXT OF SOCIAL CONSTRUCTION}

In Omi \& Winant's theory of racial formation, the racial order is reinforced through reciprocal links between the macro and micro levels of society. As examples of these links, they note how practices of racial discrimination have consequences for individual identity and how these identities, in turn, shape "the universe of collective action" (Omi \& Winant 1986, p. 68). However, much of the book is devoted to demonstrating the political contestation of racial meanings in the United States as a pitched battle between the state and social movements. Thus, although the underlying goal of a racial formation perspective is to understand how racial identities, institutions, and social practices are both intertwined and "formed and transformed over time" (Omi \& Winant 1986, 
p. 69), the weight of the work that followed has examined these processes primarily at the level of states and social movements.

Scholars who study the social construction of race from a macro perspective highlight how politics and power relations shape the racial order locally, nationally, and globally. States have interests and deploy racial categories and their associated hierarchies in service of those interests. Dominant groups maintain and police racial boundaries through social closure and violence-symbolic or otherwise-to maintain status and power. Subordinate groups challenge the overall classification scheme and the resources and rewards that follow from it. Racial categories and their social meanings are unstable and historically contingent because they are the focus of persistent political struggle (Omi \& Winant 1986, 1994).

Scholars interested in these processes typically consider how to characterize the overall racial hierarchy in societies and where the boundaries or color lines are drawn to separate insiders from outsiders, the haves from the have-nots. For example, debate continues regarding whether the color line in the contemporary United States is best described as dividing whites and nonwhites (Warren \& Twine 1997) or blacks and nonblacks (e.g., Lee \& Bean 2004), or whether it is evolving into a more complex triracial hierarchy or "pigmentocracy" (e.g., Bonilla-Silva 2004).

Similar work on boundary making has also contributed to the literature on the social construction of race and ethnicity, although it tends to take its starting point from Barth (1969). This work highlights that social boundaries in general, and racial boundaries in particular, can either be "blurry" or "bright," depending in part on whether the defining characteristics are conceptualized as achieved or ascribed (Alba 2005). Wimmer (2008) has also outlined a typology of boundary formation and change with some predictions about when the various types of contestation (boundary shifting, boundary crossing, boundary blurring, and transvaluation) might occur. For example, he suggests that ethnic boundaries will be policed more carefully in societies with a high degree of inequality compared with more egalitarian ones (Wimmer 2008).

Some empirical work at this level of analysis examines how particular racial categories, such as black, white, and Hispanic, came to be defined and applied to diverse populations (Davis 2001, Jacobson 1999, Rodriguez 2000), but much more common are case studies of the racialization of particular groups. Research on the racial positioning of Latinos in the United States, both historically (Almaguer 1994) and in contemporary society (Frank et al. 2010), epitomizes this approach. Similar studies have explored how other immigrant groups, from Filipinos (Baldoz 2004) to South Asians (Kibria 1996), situate themselves — and are situated by others-in the American racial landscape.

This focus on the consequences of outsider status is also found in recent research that explores how other characteristics or categories of difference-beyond physical features and ancestry, per se-can take on immutable, racelike qualities in particular social contexts. These studies highlight the role that racial ideology plays in the justification and maintenance of social inequality by demonstrating the invidious ways that racial discourse is used to naturalize difference and to neutralize perceived threats to social stability posed by feared "others." Examples include the racialization of Jews in medieval Europe (Thomas 2010), Muslims in contemporary Australia (Dunn et al. 2007), and migrant workers in China (Han 2010).

Similarly, many studies in the racial formation tradition examine how the explicit manipulation of racial categories and hierarchies has been central to specific nationbuilding processes (Loveman \& Muniz 2007, Seirlis 2004, Weiner 1995) as well as to practices of colonial and capitalistic exploitation more broadly (Winant 2001). Other research along these lines examines the adoption of specific policies and legislation as mechanisms of maintaining the racial order in a given society. Examples of such efforts include attempts to regulate interracial intimacy through state-level antimiscegenation laws in 
the United States (Nagel 2000, Pascoe 2009) as well as both explicit and implicit national policies on immigration in numerous countries around the world (Bashi 2004, Calavita 2007). As a result of women's roles in "reproducing" races and nations, feminist scholars add that racial projects around identity, "mixing," and citizenship are often gendered, as well (Dorr 1999, Luibheid 2004, Vacante 2007).

Recently, official practices of compiling racial and ethnic statistics have also come under the scrutiny of constructivist scholarship (Simon \& Piché 2012, Snipp 2003). This research ranges from methodological debates over how particular populations should be counted (e.g., Aspinall 2003, Hitlin et al. 2007) to critical accounts of how national censuses actively create the racial divisions they purport to catalog objectively (Kertzer \& Arel 2002, Nobles 2000). A growing literature demonstrates that such concerns are not purely academic: How race and ethnicity are measured can affect the results in quantitative studies of inequality (Bailey et al. 2013, Saperstein 2006). As governments around the world increasingly turn to national censuses to monitor racial discrimination, it has become imperative to understand the often contradictory roles that official statistics play in affirming racial hierarchies, providing social recognition, and allocating government resources (Morning \& Sabbagh 2005).

\section{EMBODYING CATEGORIES: IDENTIFICATION, PERCEPTION, AND PERFORMANCE}

Traditional micro-level work on race in sociology tends to focus on patterns of prejudice, social distance, and individual racial attitudes: What neighborhoods do people choose to live in and why, do they approve of interracial marriage, or acknowledge contemporary racial discrimination-and, if so, whom do they believe bears the brunt of it (e.g., Bobo \& Kluegel 1997)? This line of research has been critiqued for giving, or seeming to give, primacy to the behaviors and beliefs of individual people, over the institutional structures of society that are crucial sites of the reproduction of racial inequality (Bonilla-Silva 1997). Other scholars note that standard race and ethnic relations research, from either micro or macro perspectives, cannot fully embrace a constructivist approach as long as it begins by conflating racial schemas and categories with racial groups (Brubaker et al. 2004).

By definition, micro-level work on the social construction of race (and ethnicity and nationality) assumes that the allegiances and identities of individuals, and even the way people are perceived racially by others, is neither given nor obvious-or rather, if these aspects of race are believed to be fixed, the fact that they come to be seen as commonsense, immutable categorizations is a fundamental part of the racialization process. Thus, the central research question shifts from why white people discriminate against black people to why a person identifies or is perceived in a particular way, at a particular point in time.

Some of the early work of this kind focused on patterns of identification among white Americans whose ancestral origins had begun to take on more symbolic dimensions as they became less salient for their life chances (Gans 1979). By showing that middle-class white Americans exercised "ethnic options" about which parts of their ethnic background to emphasize in a given situation, Waters (1990) became the leading empirical exemplar in the emerging constructivist literature (see Figure $\mathbf{1} \boldsymbol{b}$ ). Her follow-up study on the racial identities of West Indian immigrants (Waters 1999) cemented the idea that some people have more options for identifying in multiple ways than do others and that no one's choices are entirely free from the social constraints imposed, in part, by the macro-level processes of recognition discussed above.

Research in a similar vein has gone on to establish that there are both more American Indians and more Irish Americans than can be accounted for by births, deaths, and immigration (Eschbach et al. 1998, Hout \& Goldstein 1994). Different patterns of racial identification 
among otherwise similar populations can be attributed to everything from the question wording or category options to the local racial composition, and from father's surname to mother's education (Farley 2005, Liebler 2004, Vaquera \& Kao 2006, Xie \& Goyette 1997). Overall, these studies show that how Americans answer questions about their race or ethnicity is sensitive to social context in ways that belie earlier assumptions that a person's race is static or given.

Another turning point in this area of research was the multiracial movement and the 1997 announcement by the Office of Management and Budget that all federal statistics on race were to be collected in such a way that allows Americans to "mark one or more" categories to describe their racial identities (Dacosta 2007, Hirschman 2004). Although many national surveys had been recording multiple responses to questions about race and ethnicity all along (see Saperstein 2013), the increased attention to multiraciality around the turn of the twenty-first century launched new areas of inquiry. In one of the first such efforts, Harris \& Sim (2002) used data from the National Longitudinal Study of Adolescent Health (Add Health) to show that teens who identified as multiracial when filling out a questionnaire at school did not necessarily identify as multiracial several months later when interviewed in their home. The piece has become a staple of the literature on the social construction of race (see Figure $\mathbf{1} b$ ) and generated a string of follow-up studies that have made Add Health a key source of empirical knowledge in the field (see, e.g., Bratter \& Heard 2009, Campbell 2009, Doyle \& Kao 2007).

The reliance on survey data for many of these micro-level studies has both strengths and weaknesses. On the plus side, the large sample sizes and nationally representative data call attention to the importance of these issues for all Americans-for the purposes of everything from public policy to demographic projections (Hochschild \& Weaver 2010, Perez \& Hirschman 2009). However, it has also focused attention on the process of public racial identi- fication, which is only one of the many ways to conceptualize or measure an individual's race. As scholars have increasingly argued, knowing which race boxes Americans check on a survey is not the same as knowing their ancestry, how they think of themselves privately, how they are perceived by others, or how they think others perceive them (Harris \& Sim 2002, Roth 2010, Saperstein 2006).

To the extent that sociologists have tried to tease these dimensions apart, the analytical focus often remains on the perspective of the individuals in question: what they know about their ancestry, how they incorporate it into their sense of self, how they negotiate experiences of perceived discrimination, and whether they feel their identity is validated by others (e.g., Khanna 2010, Rockquemore \& Brunsma 2002). The idea that the actual perceptions of others matter is left largely implicit in studies of a racialized "presentation of self" (Goffman 1959, West \& Fenstermaker 1995) as well. Although the race or ethnicity that people choose to "do" in public might not be consistent with their ancestry or their private sense of self (Jiménez 2010), their racial performance also might not be judged as credible or authentic by their audience (Vasquez \& Wetzel 2009, Wilkins 2004).

The lack of explicit attention to micro-level processes of categorization in sociological research on race is somewhat surprising, as by definition racial classification underlies practices of racial profiling and intentional discrimination. It is well established that Americans categorize each other by race almost automatically (Eberhardt 2005), and studies suggest that children do so as early as age three (Van Ausdale \& Feagin 1996). Furthermore, before the 1970s, most racial data in the United States was collected by observation, as recorded by census enumerators and survey interviewers. Yet there are few systematic, sociological studies of the racial perceptions of others that explicitly examine how people get assigned to different racial or ethnic categories in everyday interactions. Recent evidence from national surveys suggests that racial classifications of others 
are shaped by social status and widespread stereotypes about who is (or should be) on the top of the social hierarchy: Survey interviewers tend to whiten people with high socioeconomic status in Brazil (Telles 2002), and both whiten and darken people as they experience changes in social status in the United States (Saperstein \& Penner 2012). However, sociologists have done little to study the triggers of such judgments, the mechanisms behind them, or how they might vary by context (see Sheriff 2001 for an example from anthropology).

To gain additional insight into these issues, we turn briefly to the literature in social and cognitive psychology, where a growing body of work examines the predictors of racial categorization and cognitive stereotyping (Quadflieg \& Macrae 2011). Of particular note are a series of recent studies that suggest skin tone does not play the overriding role in shaping racial perceptions that many would expect (e.g., Bar-Haim et al. 2009, Willenbockel et al. 2011). MacLin \& Malpass (2001) also show that applying stereotyped racial markers, such as hairstyles, to otherwise similar faces results in categorizations that both are more likely to match the stereotype and tend to be remembered as more stereotypical on other dimensions (e.g., skin tone) than the face with which they were actually presented. Priming people with racially stereotyped words (e.g., "crime") or images (e.g., a gun) produces similar results (Eberhardt et al. 2004). However, attention to race can be partially offset by making other dimensions of difference more salient (Kurzban et al. 2001), and racial categorizations are complicated by introducing stereotype-inconsistent information (Richeson \& Trawalter 2005). Overall, this work demonstrates that racial perception is not simply a straightforward read of physical characteristics. Even from a cognitive perspective, the act of seeing race is a fundamentally social process (Eberhardt 2005, Freeman et al. 2011).

Though this research is not explicitly in the racial formation tradition-e.g., only one of these articles cites Omi \& Winant (1986, 1994)—we think it is important for sociologists to be aware of recent developments in these fields because they have many implications for how race could be conceptualized in our own work. Of course, the reverse is also true. We return to the issue of bridging disciplinary boundaries below.

\section{INSTITUTIONS AND INTERACTION: THE MIDDLE GROUND}

Meso-level analysis has been defined in a range of ways in sociology (Fine 2012). In the original Racial Formation, Omi \& Winant (1986) did not refer to it explicitly; rather, they included "the structuring of our practical activity" (p. 66) with micro-level concerns about the formation of identity and interactions with others. We chose to distinguish it for our purposes here because the social construction of race takes on a different emphasis in analyses of institutions and organizations. This is the terrain where official policies, racial stereotypes, and cultural representations collide with individual racial identities and perceptions. It is where "racial projects"-whether racist or egalitarian-are forced to contend with entrenched bureaucracy, institutional inertia, and the everyday grind of hiring workers, teaching students, judging cases, or diagnosing patients. Despite its sociological tenor, much of this work has been produced by scholars outside of sociology.

The racial formation perspective was quickly embraced by legal scholars, who incorporated the approach into critical race theory, also in its infancy at the time. At the heart of this critique of traditional legal scholarship is the idea that the law and race are mutually constitutive (see Carbado \& Harris 2012, Gomez 2010). That is, one cannot interpret the racial order without reference to the laws that support it, nor can one understand judicial opinions and decisions without also examining the prevailing notions of race in society and the individual racial commitments of legal actors. One of the most well-known studies in this tradition revealed the inconsistent verdicts and tortured logic used in support of white supremacy in a series of cases considering individuals' 
racial fitness for US citizenship (Haney Lopez 1996). Other similar work exposed the decisions of nineteenth-century courts in situations in which Americans' race was on trial for other reasons, such as their ability to inherit property or testify in another court proceeding. When embarrassing public examinations of physical characteristics and testimony regarding their ancestry failed to convince, courts often relied on assertions that the person in question behaved in accordance with social expectations associated with a particular race, for example, by voting or by not befriending members of other races (Gross 1998). These studies demonstrate what race means when it really matters for determining life chances: not in the abstract, as when formulating policies, but when it comes to applying those definitions and legislation to individuals in everyday life. Indeed, as Pascoe (2009) noted, one of the least explored areas of the social construction of race and the maintenance of racial hierarchy is the role of the petty bureaucrats and local government officials who were tasked with carrying out state policy-whether they liked it or not.

There is also a growing body of work on the social construction of race in the criminal justice system, broadly construed. Wacquant (2002) asserts, from a macro-level perspective, that mass imprisonment in the United States "makes race" by both drawing on and reshaping shared images of blackness, and a number of empirical studies examine the specific racial processes that shape the outcomes, and even the identities, of individuals in encounters with the criminal justice apparatus. For example, Goodman (2008) details how policies of racial segregation in California prisons shape intake interviews and the extent to which inmates are given leeway to self-identify their race on official forms. Other studies focus on how racial stereotypes about drug dealing and drug use shape racial disparities in arrests (Beckett et al. 2005), and how individuals who are perceived to have committed stereotype-congruent crimes often receive additional legal sanctions (Harris et al. 2011). Less common in this area are studies of racialization from the perspectives of police and prison workers, though Holdaway (1997) shows how race was constructed among officers in an English constabulary, and Knepper (2008) explores "counterracialization" in a study of African Americans who desegregated the justice system in North Carolina.

Education scholars were also among the early adopters of the racial formation perspective, and ethnographic research in schools has provided a particularly fruitful context for examining both the performance of race (Wilkins 2004) and the self-fulfilling prophecies of racial stereotypes that maintain racial inequality (Carter 2005). From early studies of students' fears of being seen as acting white if they appeared to be doing well in the classroom (Fordham \& Ogbu 1986, Tyson et al. 2005), school-based research on the social construction of race has gone on to show how, in both the classroom and the schoolyard, students learn race and what membership in a particular racial group means (Lewis 2003). For example, Staiger (2004) shows how the organization of a magnet program intended to support voluntary school desegregation instead helped create notions of whiteness as "giftedness" within the school. Survey research also demonstrates the racializing role of education by showing that both high levels of attainment and a lack of success in school can lead to changes in racial/ethnic identity (Feliciano 2009, Wilkinson 2010). Other work in education examines how curricular content (Morning 2008) and sponsored extracurricular organizations (Literte 2010) signal the proper way to think about race to students. The dynamics of racialization in schools also has been explored outside the United States (see, e.g., Zembylas 2010 on Cyprus).

Struggles over racial categorizations and the interpretation of racial meanings permeate the workplace as well. Numerous studies have shown how employers racialize the ideal worker and use these stereotypes to justify disparities in hiring as well as specific job assignments (e.g., Maldonado 2009, Pager et al. 2009). Ethnographic work also demonstrates how racial 
stereotypes not only govern interactions between employers and employees, but also shape the ways managers instruct their employees to relate to customers (e.g., Sallaz 2010). Some argue that the workplace itself becomes racialized as workplace cultures take the unmarked language and practices of whiteness for granted (Reitman 2006). At the same time, sociologists continue to stress that more research remains to be done on the social construction of race in the workplace (Lopez 2010), particularly in terms of understanding how individual racial identities and performances shape and are shaped by workplace outcomes (see Siebers 2009 for one such attempt in the context of Dutch tax administration).

Another frontier of crucial meso-level work on the social construction of race occurs in medical settings-both clinical and research oriented-where competing understandings of what race means are in constant tension (Braun et al. 2007, Shim 2005). For example, Fujimura \& Rajagopalan (2011) show how commonsense notions about the inheritability of race shape the research designs of genome-wide association studies searching for the causes of disease. Racialized stereotypes about who is deserving of care have also been shown to shape interactions in health clinics (Bridges 2011), and biological notions of race-and profit seeking — affect the labeling and marketing of products in the pharmaceutical industry (Kahn 2008). Sometimes, the reification of racial, biological difference occurs as an unintended consequence of policies aimed at racial justice, as when mandates to include racial minorities in clinical trials required all federally funded research to use the Office of Management and Budget's official census racial categories (Epstein 2007). At the root of the problem is how much of our medical knowledge is predicated, even contaminated, by longunexamined assumptions about when race does, or does not, matter for health (Braun 2005).

Of course, constructivist researchers have turned a critical eye to the conduct of research and the generation of racialized knowledge in their own fields as well. Indeed, much of what might be termed meso-level work in the racial formation tradition takes on everything from the practices of ethnography (Morris 2007) and interviewing (Best 2003) to the use of standard regression analysis and the interpretation of results (Martin \& Yeung 2003, Stewart 2008). Critical reflections on the conceptualization of race in the academy include management (Nkomo 1992), forensic anthropology (Brace 1995), geography (Bonnett 1996), library sciences (Furner 2007), mathematics education (e.g., Martin 2009), and sociology (e.g., Emirbayer \& Desmond 2012), just to name a few. At the heart of many of these concerns is how to avoid essentializing race and racial groups even as we take them as our objects of study (Daynes \& Lee 2008, Hartigan 2000). The question of how to incorporate insights from the social construction of race into university teaching has received considerable attention from sociologists as well (e.g., Obach 1999, Townsley 2007).

\section{BRIDGING ACADEMIC BOUNDARIES}

Thus far, we have reviewed the literature on the social construction of race as if it were divisible into ideal-type groupings by primary level of analysis. As with all typologies, some examples fit better than others, and taken together these studies likely array themselves on something more like a spectrum from the most micro concerns about the racial identity and presentation of self for a single individual (e.g., Bailey 2000) to the most macro theorizing about the historical, comparative, and global nature of race and racism (e.g., Dikotter 2008). However, by summarizing typical research approaches and findings at the macro, micro, and meso levels separately, we also aim to highlight the need for work on racial formation that links multiple levels of analysis. These efforts to bridge the macro-micro, macro-meso, and meso-micro perspectives bring us closer to understanding the full range of processes that shape racial categories, shift racial meanings, and ultimately support the racial order. Much of this work has been published in the past 
few years, which seems to signal an important advance in the way the social construction of race is being studied in sociology and beyond.

As noted above, one way to link macro concerns with color lines and racial hierarchies to meso perspectives on the workings of institutions is to examine how social boundaries and policies get translated into organizational practice. For example, Lee \& Skrentny (2010) contrast whether federal mandates regarding official racial classification schemes were contested, or not, in various fields from pharmaceutical development to equal opportunity employment regulations. Similarly, Garb (2006) shows how the metaphorical color line was imposed in Chicago neighborhoods through real estate markets, and Sallaz (2010) reveals the postapartheid racialization of consumers by contrasting the frontstage and backstage marketing practices of a South African firm. Linking differential racialization with different levels of political organization, Aptekar (2009) finds that Asian Indians, racialized as "troublemakers," engage in more political activity through their community organizations, compared with their Chinese counterparts, who are marked by the more benign "model minority" stereotype.

Work that bridges the meso and micro levels most commonly examines how a particular context shapes the racial interactions and racial identities of individuals, as in the examples of research on racialization in the criminal justice system discussed above. However, the effects of institutional or social context are revealed even more clearly in studies that explicitly contrast how race is constructed or experienced differently in different settings. For example, Moore (2003) compares interactions among children in a predominantly white and a multiracial summer camp and finds both similarities and differences in the negotiation of the children's playgroups and racial identities (see also Lewis 2003). Wilkinson (2011) takes another approach to the question of how race is negotiated by individuals in organizational contexts by analyzing how questions about racial/ethnic identification are asked, answered, and ulti- mately recorded in the monitoring statistics for a British telephone helpline. The transcripts of these calls reveal the complex negotiation of racial meanings hidden under the tidy percentages of "White Europeans," "Black British," and others presented in the quantitative data.

Recent research also reminds us of the importance of attending to the effects of larger macro conceptions of race on the identities and perceptions of individuals, mediated not only through institutions, as in the examples above, but also more directly, as people form conceptions of themselves and others through the lens of broader political struggles, cultural representations, and stereotypes. For example, work in the United States explores how perceived discrimination and the broader context of immigrant reception shapes individuals' racial and ethnic identities (Golash-Boza \& Darity 2008, Rumbaut 2008). Light \& Iceland (2012) continue this line of research but make the macro-micro connection even more explicit by examining whether the likelihood that self-identified Latinos will choose "some other race" (as opposed to one of the official racial categories) varies by levels of metropolitan segregation and reported hate crimes. Studies of attempts to institute affirmative action policies in Brazil also clearly reveal the challenges of legislating race from the top down, without taking into account beliefs about race entrenched at the bottom. As Bailey (2008) and Schwartzman (2009) show, the binary distinction between "brancos" and "negros" that describes societal-level racial inequality and was recently adopted in affirmative action policies does not resonate with how most Brazilians describe themselves and others and whom they judge to be deserving of such assistance.

Contrasting perspectives on racial formation from different levels of analysis also reveal the remaining gaps in our knowledge. For example, although racial discrimination clearly exists, how people are initially categorized by race and thus singled out for discrimination is less clear. That is, how do the dynamics of racial classification operate, not just at the macro level in lobbying for group recognition 
(see, e.g., Skerry 2000), but also at the meso and micro levels, as individuals and institutions set group boundaries and determine when such categorizations should have meaning? Similarly, if we do not assume that racial categorization is or should be obvious, then what are the specific cues people use to classify someone by race? How do these racial cues vary by context and to what extent can they be manipulated in performance? Perhaps most importantly, we should not take for granted the seeming stability in racial hierarchies or supposed normative agreement about racial classifications in the past (cf. Fox \& Guglielmo 2012, Williamson 1995). Contested categories at the macro level and fluid and complex identities and performances at the micro level coexist with persistent racial inequality in the present. Yet the social processes that generate stability out of flexibility likely predate the current, allegedly postracial, multicultural era in the United States. The durability of racial inequality in the face of both political contestation and individual identity work is a provocative and underexplored area of research on the social construction of race that explicitly demands the kind of multilevel dialogue we advocate here.

\section{RECOMMENDATIONS FOR FUTURE RESEARCH}

A quarter of a century after Omi \& Winant took their first steps "towards a racial formation perspective" (Omi \& Winant 1986, p. 52), an impressive and varied body of work has followed them-spanning disciplines, methods, and levels of analysis. As this review shows, when sociologists need to demonstrate the social construction of race, they have an array of examples to choose from. These examples extend beyond explicit discussions of race and ethnicity, speaking to concerns in a range of fields, including immigration, social policy, work and organizations, education, social psychology, and the determinants of health.

However, this corpus of work has yet to make a significant impression on the broader body of sociological research. Despite its powerful critique of what race means and how it functions in society, the constructivist approach remains concentrated in specific subjects even within the sociological literature on race and inequality (see Figure 2). This is surely a two-way street: Although inequality scholars have made little effort to incorporate a racial formation perspective in their work, constructivist scholars also tend to focus rather narrowly on racial construction for its own sake. Methodological and ideological divides have contributed to this silo-ing, also perpetuated by both sides.

Nevertheless, to remain vibrant and advance scholarship, research on the social construction of race must look outside of itself, to communicate its unique findings and their relevance to other subfields of sociology, as well as other disciplines. Some recent scholarship is already making these efforts. For example, Ellis et al. (2007) demonstrate how taking into account the possibility of being multiracial at both the individual and household levels changes our perspective on residential segregation, and Saperstein \& Penner (2012) explore the relationship between individual racial fluidity and social inequality in the United States.

A key part of this effort also requires being explicit about how a constructivist approach to race and ethnicity changes (or should change) the standard practices of research. There are many critiques and calls for better, more reflexive, and more critical approaches to race and ethnicity but few straightforward empirical examples for people, especially graduate students and the next generation of scholars, to follow. We highlighted several of these studies above, and their insights-about conceptualizing race from multiple perspectives (Morris 2007, Roth 2010, Saperstein 2006) and being more circumspect about interpreting results in quantitative analyses (e.g., Martin \& Yeung 2003, Stewart 2008) — can and should be addressed in standard courses on research methods.

Of course, scholars who self-consciously ally with a racial formation perspective cannot and should not make these outreach efforts alone. Amid calls to better understand the mechanisms 
behind discrimination and persistent inequality (e.g., Reskin 2000), sociologists who ignore the social construction of race do so at the expense of fully exploring the processes at play. For example, research in the sociology of work advances our understanding of inequality by demonstrating how powerful actors use novel techniques to maintain racial hierarchies, as in the relationship between human resource policies and contemporary forms of discrimination in the workplace (Light et al. 2011). Yet this body of work rarely considers the reciprocal micro-level processes of racialization that also affect perceptions of workers and perhaps set the conditions for future inequality. Conscious efforts to make these connections-between theoretical and empirical perspectives, across subfields, and at different levels of analysis - will unite the best work on labor market discrimination, cognitive psychology, public health, and so on, with the best work on the social construction of race to inspire new research programs and develop a more complete picture of social inequality.

\section{DISCLOSURE STATEMENT}

The authors are not aware of any affiliations, memberships, funding, or financial holdings that might be perceived as affecting the objectivity of this review.

\section{ACKNOWLEDGMENTS}

We are grateful for the research assistance of Ariela Schachter and Susan Fisk. We also thank jimi adams, Stan Bailey, Mara Loveman, Jim Moody, and the members of the Stanford Migration, Race, Ethnicity and Nation Workshop for their helpful comments and suggestions. Any remaining errors or omissions are our own.

\section{LITERATURE CITED}

Alba R. 2005. Bright versus blurred boundaries: second-generation assimilation and exclusion in France, Germany, and the United States. Ethn. Racial Stud. 28:20-49

Almaguer T. 1994. Racial Fault Lines: The Historical Origins of White Supremacy in California. Berkeley: Univ. Calif. Press

Aptekar S. 2009. Organizational life and political incorporation of two Asian immigrant groups: a case study. Ethn. Racial Stud. 32:1511-33

Aspinall PJ. 2003. The conceptualisation and categorisation of mixed race/ethnicity in Britain and North America: identity options and the role of the state. Int. F. Intercult. Relat. 27:269-96

Bailey B. 2000. Language and negotiation of ethnic/racial identity among Dominican Americans. Lang. Soc. 29:555-82

Bailey SR. 2008. Unmixing for race making in Brazil. Am. F. Sociol. 114:577-614

Bailey SR, Loveman M, Muniz JO. 2013. Measures of "race" and the analysis of racial inequality in Brazil. Soc. Sci. Res. 42:106-19

Baldoz R. 2004. Valorizing racial boundaries: hegemony and conflict in the racialization of Filipino migrant labour in the United States. Ethn. Racial Stud. 27:969-86

Banton M. 2012. The colour line and the colour scale in the twentieth century. Ethn. Racial Stud. 35:1109-31

Bar-Haim Y, Saidel T, Yovel G. 2009. The role of skin colour in face recognition. Perception 38:145-48

Barot R, Bird J. 2001. Racialization: the genealogy and critique of a concept. Ethn. Racial Stud. 24:601-18

Barth F. 1969. Introduction. In Ethnic Groups and Boundaries: The Social Organization of Cultural Difference, ed. F Barth, pp. 9-38. London: Allen \& Unwin

Bashi V. 2004. Globalized anti-blackness: transnationalizing Western immigration law, policy, and practice. Ethn. Racial Stud. 27:584-606

Batagelj V, Mrvar A. 1998. Pajek—a program for large network analysis. Connections 21:47-57 
Beckett K, Nyrop K, Pfingst L, Bowen M. 2005. Drug use, drug possession arrests, and the question of race: lessons from Seattle. Soc. Probl. 52:419-41

Berger PL, Luckman T. 1966. The Social Construction of Reality: A Treatise in the Sociology of Knowledge. Garden City, NY: Doubleday

Best AL. 2003. Doing race in the context of feminist interviewing: constructing whiteness through talk. Qual. Inq. 9:895-914

Bobo L, Kluegel JR. 1997. Status, ideology and dimensions of whites' racial beliefs and attitudes: progress and stagnation. In Racial Attitudes in the 1990s: Continuity and Change, ed. SA Tuch, JK Martin, pp. 93-120. Greenwood, CT: Praeger

Bobo LD, Fox C. 2003. Race, racism, and discrimination: bridging problems, methods, and theory in social psychological research. Soc. Psychol. Q. 66:319-32

Bonilla-Silva E. 1997. Rethinking racism: toward a structural interpretation. Am. Sociol. Rev. 62:465-80

Bonilla-Silva E. 2004. From bi-racial to tri-racial: towards a new system of racial stratification in the USA. Ethn. Racial Stud. 27:931-50

Bonnett A. 1996. Constructions of "race," place and discipline: geographies of "racial" identity and racism. Etbn. Racial Stud. 19:864-83

Brace CL. 1995. Region does not mean race-reality versus convention in forensic anthropology. F. Forensic Sci. $40: 171-75$

Bratter J, Heard HE. 2009. Mother's, father's, or both? Parental gender and parent-child interactions in the racial classification of adolescents. Sociol. Forum 24:658-88

Braun L. 2005. Spirometry, measurement, and race in the nineteenth century. F. Hist. Med. Allied Sci. 60:135-69

Braun L, Fausto-Sterling A, Fullwiley D, Hammonds EM, Nelson A, et al. 2007. Racial categories in medical practice: How useful are they? PLoS Med. 4:1423-28

Bridges KM. 2011. Reproducing Race: An Ethnography of Pregnancy as a Site of Racialization. Berkeley: Univ. Calif. Press

Brubaker R. 2009. Ethnicity, race, and nationalism. Annu. Rev. Sociol. 35:21-42

Brubaker R, Loveman M, Stamatov P. 2004. Ethnicity as cognition. Theory Soc. 33:31-64

Calavita K. 2007. Immigration law, race, and identity. Annu. Rev. Law Soc. Sci. 3:1-20

Campbell ME. 2009. Multiracial groups and educational inequality: a rainbow or a divide? Soc. Probl. 56:425-46

Carbado DW, Harris CI. 2012. The new racial preferences: rethinking racial projects. See HoSang et al. 2012 , pp. 183-212

Carter P. 2005. Keepin' It Real: School Success in Black and White. New York: Oxford Univ. Press

DaCosta K. 2007. Making Multiracials: State, Family and Market in the Redrawing of the Color Line. Stanford, CA: Stanford Univ. Press

Davis FJ. 2001. Who Is Black? One Nation's Definition. University Park: Pa. State Univ. Press

Daynes S, Lee O. 2008. Desire for Race. New York: Cambridge Univ. Press

Dikotter F. 2008. The racialization of the globe: an interactive interpretation. Ethn. Racial Stud. 31:1478-96

Dorr LL. 1999. Arm in arm: gender, eugenics and Virginia's Racial Integrity Acts of the 1920s. 7. Women's Hist. 11:143-66

Douglas RM. 2002. Anglo-Saxons and Attacotti: the racialization of Irishness in Britain between the world wars. Ethn. Racial Stud. 25:40-63

Doyle JM, Kao G. 2007. Are racial identities of multiracials stable? Changing self-identification among single and multiple race individuals. Soc. Psychol. Q. 70:405-23

Du Bois WEB. 1899. The Philadelphia Negro. Philadelphia: Univ. Pa. Press

Dunn KM, Klocker N, Salabay T. 2007. Contemporary racism and Islamaphobia in Australia-racializing religion. Ethnicities 7:564-89

Eberhardt JL. 2005. Imaging race. Am. Psychol. 60:181-90

Eberhardt JL, Goff PA, Purdie VJ, Davies PG. 2004. Seeing Black: race, crime, and visual processing. $\mathcal{F}$. Personal. Soc. Psychol. 87:876-93

Ellis M, Holloway S, Wright R, East M. 2007. The effects of mixed-race households on residential segregation. Urban Geogr. 28:554-77

Emirbayer M, Desmond M. 2012. Race and reflexivity. Ethn. Racial Stud. 35:574-99 
Epstein S. 2007. Inclusion: The Politics of Difference in Medical Research. Chicago: Univ. Chicago Press

Eschbach K, Supple K, Snipp CM. 1998. Changes in racial identification and the educational attainment of American Indians, 1970-1990. Demography 35:35-43

Farley R. 2005. Racial identities in 2000: the response to the multiple-race response option. In The New Race Question: How the Census Counts Multiracial Individuals, ed. J Perlmann, MC Waters, pp. 33-61. New York: Russell Sage Found.

Feliciano C. 2009. Education and ethnic identity formation among children of Latin American and Caribbean immigrants. Sociol. Perspect. 52:135-58

Fine GA. 2012. Group culture and the interaction order: local sociology on the meso-level. Annu. Rev. Sociol. 38:159-79

Fordham S, Ogbu JU. 1986. Black students' school success: coping with the "burden of 'acting White'." Urban Rev. 18:176-206

Fox C, Guglielmo TA. 2012. Defining America's racial boundaries: Blacks, Mexicans, and European immigrants, 1890-1945. Am. 7. Sociol. 118:327-79

Frank R, Akresh IR, Lu B. 2010. Latino immigrants and the U.S. racial order: How and where do they fit in? Am. Sociol. Rev. 75:378-401

Frederickson G. 2002. Racism: A Short History. Princeton, NJ: Princeton Univ. Press

Freeman JB, Penner AM, Saperstein A, Scheutz M, Ambady N. 2011. Looking the part: social status cues shape race perception. PLoS ONE 6:e25107

Fujimura JH, Rajagopalan R. 2011. Different differences: the use of "genetic ancestry" versus race in biomedical human genetic research. Soc. Stud. Sci. 41:5-30

Furner J. 2007. Dewey deracialized: a critical race-theoretic perspective. Knowledge Organ. 34:144-68

Gans HJ. 1979. Symbolic ethnicity: the future of ethnic groups and cultures in America. Ethn. Racial Stud. $2: 1-20$

Garb M. 2006. Drawing the "color line"-race and real estate in early twentieth-century Chicago. 7. Urban Hist. 32:773-87

Girvan M, Newman MEJ. 2002. Community structure in social and biological networks. Proc. Natl. Acad. Sci. USA 99:7821-26

Goffman E. 1959. The Presentation of Self in Everyday Life. Garden City, NY: Doubleday

Golash-Boza T, Darity W. 2008. Latino racial choices: the effects of skin colour and discrimination on Latinos' and Latinas' racial self-identifications. Ethn. Racial Stud. 31:899-934

Gomez LE. 2010. Understanding law and race as mutually constitutive: an invitation to explore an emerging field. Annu. Rev. Law Soc. Sci. 6:487-505

Goodman P. 2008. "It's Just Black, White, or Hispanic": an observational study of racializing moves in California's segregated prison reception centers. Law Soc. Rev. 42:735-70

Gravlee CC, Bernard HR, Leonard WR. 2003. Heredity, environment, and cranial form: a reanalysis of Boas's immigrant data. Am. Anthropol. 105:125-38

Gross AJ. 1998. Litigating whiteness: trials of racial determination in the nineteenth-century South. Yale Law 7. $108: 109-88$

Hacking I. 1999. The Social Construction of What? Cambridge, MA: Harvard Univ. Press

Han D. 2010. Policing and racialization of rural migrant workers in Chinese cities. Ethn. Racial Stud. 33:593610

Haney Lopez I. 1996. White by Law: The Legal Construction of Race. New York: NYU Press

Harris A, Evans H, Beckett K. 2011. Courtesy stigma and monetary sanctions: toward a socio-cultural theory of punishment. Am. Sociol. Rev. 76:234-64

Harris DR, Sim JJ. 2002. Who is multiracial? Assessing the complexity of lived race. Am. Sociol. Rev. 67:614-27

Hartigan J. 2000. Object lessons in whiteness: antiracism and the study of white folks. Identities-Glob. Stud. Cult. Power 7:373-406

Hirschman C. 2004. The origins and demise of the concept of race. Popul. Dev. Rev. 30:385-415

Hitlin S, Brown JS, Elder GH. 2007. Measuring Latinos: racial versus ethnic classification and selfunderstandings. Soc. Forces 86:587-611

Hochschild J, Weaver VM. 2010. "There's no one as Irish as Barack O'bama": the policy and politics of American multiracialism. Perspect. Polit. 8:737-59 
Holdaway S. 1997. Constructing and sustaining "race" within the police workforce. Br. F. Sociol. 48:19-34

HoSang DM, LaBennett O, Pulido L, eds. 2012. Racial Formation in the Twenty-First Century. Berkeley: Univ. Calif. Press

Hout M, Goldstein JR. 1994. How 4.5 million Irish immigrants became 40 million Irish Americans: demographic and subjective aspects of the ethnic composition of white Americans. Am. Sociol. Rev. 59:64-82

Jacobson MF. 1999. Whiteness of a Different Color: European Immigrants and the Alchemy of Race. Cambridge, MA: Harvard Univ. Press

Jenkins R. 1997. Retbinking Ethnicity: Arguments and Explorations. London: Sage

Jiménez TR. 2010. Affiliative ethnic identity: a more elastic link between ethnic ancestry and culture. Ethn. Racial Stud. 33:1756-75

Kahn J. 2008. Exploiting race in drug development: BiDil's interim model of pharmacogenomics. Soc. Stud. Sci. 38:737-58

Kertzer DI, Arel D. 2002. Census and Identity: The Politics of Race, Ethnicity, and Language in National Censuses. New York: Cambridge Univ. Press

Khanna N. 2010. "If you're half black, you're just black": reflected appraisals and the persistence of the one-drop rule. Sociol. Q. 51:96-121

Kibria N. 1996. Not Asian, Black or White? Reflections on South-Asian-American racial identity. Amerasian 7. 22:77-86

Knepper P. 2008. Rethinking the racialization of crime: the significance of black firsts. Etbn. Racial Stud. 31:503-23

Kolchin P. 1987. Unfree Labor: American Slavery and Russian Serfdom. Cambridge, MA: Belknap

Kurzban R, Tooby J, Cosmides L. 2001. Can race be erased? Coalitional computation and social categorization. Proc. Natl. Acad. Sci. USA 98:15387-92

Lamont M, Molnár V. 2002. The study of boundaries in the social sciences. Annu. Rev. Sociol. 28:167-95

Lee C, Skrentny JD. 2010. Race categorization and the regulation of business and science. Law Soc. Rev. 44:617-49

Lee J, Bean FD. 2004. America's changing color lines: immigration, race/ethnicity, and multiracial identification. Annu. Rev. Sociol. 30:221-42

Lewis AE. 2003. Race in the Schoolyard: Negotiating the Color Line in Classrooms and Communities. New Brunswick, NJ: Rutgers Univ. Press

Liebler CA. 2004. Ties on the fringes of identity. Soc. Sci. Res. 33:702-23

Light MT, Iceland J. 2012. The social context of racial boundary negotiations: segregation, hate crime and Hispanic racial identity in metropolitan America. Presented at Annu. Meet. Popul. Assoc. Am., May 3-5, San Francisco. http://paa2012.princeton.edu/abstracts/120210

Light R, Roscigno VJ, Kalev A. 2011. Racial discrimination, interpretation, and legitimation at work. Ann. Am. Acad. Polit. Soc. Sci. 634:39-59

Literte PE. 2010. Revising race: how biracial students are changing and challenging student services. F. Coll. Stud. Dev. 51:115-34

Lopez SH. 2010. Workers, managers, and customers. Work Occup. 37:251-71

Loveman M. 1999. Is "race" essential? Am. Sociol. Rev. 64:891-98

Loveman M, Muniz JO. 2007. How Puerto Rico became white: boundary dynamics and intercensus racial reclassification. Am. Sociol. Rev. 72:915-39

Luibheid E. 2004. Childbearing against the state? Asylum seeker women in the Irish Republic. Women's Stud. Int. Forum 27:335-49

MacLin OH, Malpass RS. 2001. Racial categorization of faces-the ambiguous race face effect. Psychol. Public Policy Law 7:98-118

Maldonado MM. 2009. "It is their nature to do menial labour": the racialization of "Latino/a workers" by agricultural employers. Ethn. Racial Stud. 32:1017-36

Martin DB. 2009. Researching race in mathematics education. Teach. Coll. Rec. 111:295-338

Martin JL, Yeung KT. 2003. The use of the conceptual category of race in American sociology, 1937-99. Sociol. Forum 18:521-43

Montagu A. 1942. Man's Most Dangerous Myth: The Fallacy of Race. Walnut Creek, CA: Rowman \& Littlefield 
Moore VA. 2003. Kids' approaches to whiteness in racially distinct summer day camps. Sociol. Q. 44:505-22

Morning A. 2008. Reconstructing race in science and society: biology textbooks, 1952-2002. Am. 7. Sociol. 114:S106-37

Morning A, Sabbagh D. 2005. From sword to plowshare: using race for discrimination and antidiscrimination in the United States. Int. Soc. Sci. 7. 57:57-73

Morris EW. 2007. Researching race: identifying a social construction through qualitative methods and an interactionist perspective. Symb. Interact. 30:409-25

Nagel J. 2000. Ethnicity and sexuality. Annu. Rev. Sociol. 26:107-33

Nkomo SM. 1992. The emperor has no clothes-rewriting race in organizations. Acad. Manag. Rev. 17:487513

Nobles M. 2000. Shades of Citizenship: Race and the Census in Modern Politics. Stanford, CA: Stanford Univ. Press

Obach BK. 1999. Demonstrating the social construction of race. Teach. Sociol. 27:252-57

Omi M, Winant H. 1986. Racial Formation in the United States: From the 1960s to the 1980s. New York: Routledge

Omi M, Winant H. 1994. Racial Formation in the United States: From the 1960s to the 1990s. New York: Routledge

Pager D, Bonikowski B, Western B. 2009. Discrimination in a low-wage labor market: a field experiment. Am. Sociol. Rev. 74:777-99

Pascoe P. 2009. What Comes Naturally: Miscegenation Law and the Making of Race in America. New York: Oxford Univ. Press

Patterson O. 1997. The Ordeal of Integration: Progress and Resentment in America's "Racial" Crisis. Washington, DC: Counterpoint/Civitas Books

Perez AD, Hirschman C. 2009. Estimating net interracial mobility in the United States: a residual methods approach. Sociol. Methodol. 39:31-71

Quadflieg S, Macrae CN. 2011. Stereotypes and stereotyping: What's the brain got to do with it? Eur. Rev. Soc. Psychol. 22:215-73

Reitman M. 2006. Uncovering the white place: whitewashing at work. Soc. Cult. Geogr. 7:267-82

Reskin BF. 2000. The proximate causes of employment discrimination. Contemp. Sociol. 29:319-28

Richeson JA, Trawalter S. 2005. On the categorization of admired and disliked exemplars of admired and disliked racial groups. F. Personal. Soc. Psychol. 89:517-30

Rockquemore KA, Brunsma DL. 2002. Socially embedded identities: theories, typologies, and processes of racial identity among black/white biracials. Sociol. Q. 43:335-56

Rodriguez CE. 2000. Changing Race: Latinos, the Census and the History of Ethnicity in the United States. New York: NYU Press

Roth WD. 2010. Racial mismatch: the divergence between form and function in data for monitoring racial discrimination of Hispanics. Soc. Sci. Q. 91:1288-311

Rumbaut RG. 2008. Reaping what you sow: immigration, youth, and reactive ethnicity. Appl. Dev. Sci. 12:10811

Sallaz JJ. 2010. Talking race, marketing culture: the racial habitus in and out of apartheid. Soc. Probl. 57:294314

Saperstein A. 2006. Double-checking the race box: examining inconsistency between survey measures of observed and self-reported race. Soc. Forces 85:57-74

Saperstein A. 2013. Representing the multidimensionality of race in survey research. In Mapping Race: Critical Approaches to Health Disparities Research, ed. LE Gomez, N Lopez, pp. 190-209. New Brunswick, NJ: Rutgers Univ. Press

Saperstein A, Penner AM. 2012. Racial fluidity and inequality in the United States. Am. F. Sociol. 118:676-727

Schwartzman LF. 2009. Seeing like citizens: unofficial understandings of official racial categories in a Brazilian university. 7. Latin Am. Stud. 41:221-50

Seirlis JK. 2004. Islands and autochthons-coloureds, space and belonging in Rhodesia and Zimbabwe (Part 1). F. Soc. Archaeol. 4:405-26

Sheriff RE. 2001. Dreaming Equality: Color, Race and Racism in Urban Brazil. Piscataway, NJ: Rutgers Univ. Press 
Shim JK. 2005. Constructing 'race' across the science-lay divide: racial formation in the epidemiology and experience of cardiovascular disease. Soc. Stud. Sci. 35:405-36

Siebers H. 2009. Struggles for recognition: the politics of racioethnic identity among Dutch national tax administrators. Scand. 7. Manag. 25:73-84

Simon P, Piché V. 2012. Accounting for ethnic and racial diversity: the challenge of enumeration. Ethn. Racial Stud. 35:1357-65

Skerry P. 2000. Counting on the Census: Race, Group Identity and the Evasion of Politics. Washington, DC: Brookings Inst.

Smedley A. 2007. Race in North America: Origin and Evolution of a Worldview. Boulder, CO: Westview

Snipp CM. 2003. Racial measurement in the American Census: past practices and implications for the future. Annu. Rev. Sociol. 29:563-88

Snowden F. 1983. Before Color Prejudice: The Ancient View of Blacks. Cambridge, MA: Harvard Univ. Press

Sollors W. 2005. What race are you? In The New Race Question: How the Census Counts Multiracial Individuals, ed. J Perlmann, MC Waters, pp. 263-68. New York: Russell Sage Found.

Staiger A. 2004. Whiteness as giftedness: racial formation at an urban high school. Soc. Probl. 51:161-81

Stewart QT. 2008. Chasing the race effect: an analysis of traditional quantitative research on race in sociology. In Racism in Post-Race America: New Theories, New Directions, ed. C Gallagher. Chapel Hill, NC: Social Forces

Telles EE. 2002. Racial ambiguity among the Brazilian population. Ethn. Racial Stud. 25:415-41

Telles EE, Sue CA. 2009. Race mixture: boundary crossing in comparative perspective. Annu. Rev. Sociol. 35:129-46

Thomas JM. 2010. The racial formation of medieval Jews: a challenge to the field. Etbn. Racial Stud. 33:173755

Tilly C. 1999. Durable Inequality. Berkeley: Univ. Calif. Press

Townsley E. 2007. The social construction of social facts: using the US Census to examine race as a scientific and moral category. Teach. Sociol. 35:223-38

Tyson K, Darity W Jr, Castellino DR. 2005. It's not "a black thing": understanding the burden of acting white and other dilemmas of high achievement. Am. Sociol. Rev. 70:582-605

Vacante J. 2007. Evolving racial identity and the consolidation of men's authority in early twentieth-century Quebec. Can. Hist. Rev. 88:413-38

Van Ausdale D, Feagin JR. 1996. Using racial and ethnic concepts: the critical case of very young children. Am. Sociol. Rev. 61:779-93

Vaquera E, Kao G. 2006. The implications of choosing "no race" on the salience of Hispanic identity: how racial and ethnic backgrounds intersect among Hispanic adolescents. Sociol. Q. 47:375-96

Vasquez JM, Wetzel C. 2009. Tradition and the invention of racial selves: symbolic boundaries, collective authenticity, and contemporary struggles for racial equality. Ethn. Racial Stud. 32:1557-75

Wacquant L. 1997. For an analytic of racial domination. Polit. Power Soc. Theory 11:221-34

Wacquant L. 2002. From slavery to mass incarceration: rethinking the "race question" in the US. New Left Rev. 13:41-60

Warren JW, Twine FW. 1997. White Americans, the new minority? Non-blacks and the ever-expanding boundaries of whiteness. F. Black Stud. 28:200-18

Waters MC. 1990. Ethnic Options: Choosing Identities in America. Berkeley: Univ. Calif. Press

Waters MC. 1999. Black Identities: West Indian Immigrant Dreams and American Realities. Cambridge, MA: Harvard Univ. Press

Weber M. 1978. Ethnic groups. In Economy and Society: An Outline of Interpretive Sociology, pp. 385-99. Berkeley: Univ. Calif. Press

Weiner M. 1995. Discourses of race, nation and empire in pre-1945 Japan. Ethn. Racial Stud. 18:433-56

West C, Fenstermaker S. 1995. Doing difference. Gend. Soc. 9:8-37

Wilkins AC. 2004. Puerto Rican wannabes-sexual spectacle and the marking of race, class, and gender boundaries. Gend. Soc. 18:103-21

Wilkinson L. 2010. Inconsistent Latino self-identification in adolescence and academic performance. Race Soc. Probl. 2:179-94 
Wilkinson S. 2011. Constructing ethnicity statistics in talk-in-interaction: producing the "White European." Discourse Soc. 22:343-61

Willenbockel V, Fiset D, Tanaka JW.2011. Relative influences of lightness and facial morphology on perceived race. Perception 40:621-24

Williamson J. 1995. New People: Miscegenation and Mulattoes in the United States. Baton Rouge: La. State Univ. Press

Wimmer A. 2008. The making and unmaking of ethnic boundaries: a multilevel process theory. Am. F. Sociol. 113:970-1022

Winant H. 2000. Race and race theory. Annu. Rev. Sociol. 26:169-85

Winant H. 2001. The World Is a Ghetto: Race and Democracy Since World War II. New York: Basic Books

Xie Y, Goyette K. 1997. The racial identification of biracial children with one Asian parent: evidence from the 1990 Census. Soc. Forces 76:547-70

Zembylas M. 2010. Greek-Cypriot teachers' constructions of Turkish-speaking children's identities: critical race theory and education in a conflict-ridden society. Ethn. Racial Stud. 33:1372-91 


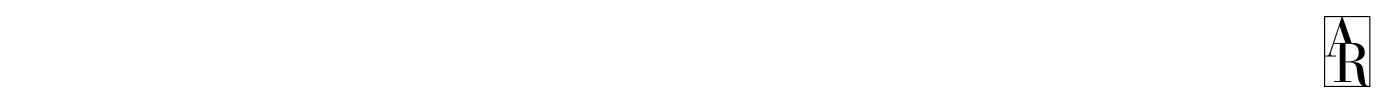

\section{Contents}

Annual Review of Sociology

Volume 39, 2013

Frontispiece

Charles Tilly ............................................................. xiv

\section{Prefatory Chapter}

Formations and Formalisms: Charles Tilly and the Paradox of the Actor Fobn Krinsky and Ann Mische 1

\section{Theory and Methods}

The Principles of Experimental Design and Their Application in Sociology Michelle fackson and D.R. Cox

The New Sociology of Morality Steven Hitlin and Stephen Vaisey

\section{Social Processes}

Social Scientific Inquiry Into Genocide and Mass Killing: From Unitary Outcome to Complex Processes Peter B. Owens, Yang Su, and David A. Snow

Interest-Oriented Action Lyn Spillman and Micbael Strand

Drugs, Violence, and the State Bryan R. Roberts and Yu Chen

Healthcare Systems in Comparative Perspective: Classification, Convergence, Institutions, Inequalities, and Five Missed Turns Jason Beckfield, Sigrun Olafsdottir, and Benjamin Sosnaud ...

\section{Institutions and Culture}

Multiculturalism and Immigration: A Contested Field in Cross-National Comparison Ruud Koopmans

Sociology of Fashion: Order and Change

Patrik Aspers and Frédéric Godart 
Religion, Nationalism, and Violence: An Integrated Approach

Philip S. Gorski and Gülay Türkmen-Dervişoğlu

\section{Formal Organizations}

Race, Religious Organizations, and Integration

Korie L. Edwards, Brad Christerson, and Michael O. Emerson

\section{Political and Economic Sociology}

An Environmental Sociology for the Twenty-First Century

David N. Pellow and Hollie Nyseth Brehm

Economic Institutions and the State: Insights from Economic History

Henning Hillmann

\section{Differentiation and Stratification}

Demographic Change and Parent-Child Relationships in Adulthood Fudith A. Seltzer and Suzanne M. Bianchi

\section{Individual and Society}

Gender and Crime

Candace Kruttschnitt

White-Collar Crime: A Review of Recent Developments and

Promising Directions for Future Research

Sally S. Simpson

From Social Structure to Gene Regulation, and Back: A Critical

Introduction to Environmental Epigenetics for Sociology

Hannab Landecker and Aaron Panofsky

Racial Formation in Perspective: Connecting Individuals, Institutions, and Power Relations

Aliya Saperstein, Andrew M. Penner, and Ryan Light

The Critical Sociology of Race and Sport: The First Fifty Years Ben Carrington

\section{Demography}

The Causal Effects of Father Absence

Sara McLanahan, Laura Tach, and Daniel Schneider

International Migration and Familial Change in Communities of Origin: Transformation and Resistance

Patricia Arias

Trends and Variation in Assortative Mating: Causes and Consequences

Christine R. Schwartz 451 
Gender and International Migration: Contributions and Cross-Fertilizations

Gioconda Herrera

LGBT Sexuality and Families at the Start of the Twenty-First Century

Mignon R. Moore and Michael Stambolis-Rubstorfer

\section{Urban and Rural Community Sociology}

Housing: Commodity versus Right

Mary Pattillo

\section{Indexes}

Cumulative Index of Contributing Authors, Volumes 30-39 ..................... 533

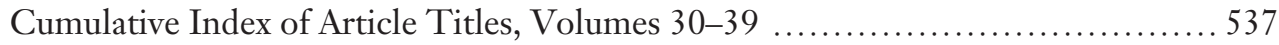

Errata

An online log of corrections to Annual Review of Sociology articles may be found at http://soc.annualreviews.org/errata.shtml 